\title{
BENCE JONES PROTEIN - THE FIRST TUMOUR MARKER IN HISTORY OF MEDICINE
}

\author{
Nenad Govedarović
}

\begin{abstract}
Bence Jones protein is generally accepted term for protein described in urine of myeloma patients. Today, qualitative, as well as quantitative determination of Bence Jones protein serve as routine analyses for diagnosis and screening of myeloma and skeletal affections. Although Bence Jones is not the first to recognize the characteristics of the urine of the diseased, his merit is that he recognized the importance of this protein in patients with myeloma. $\mathrm{He}$ is considered as the pioneer in medical chemistry and is one of the first doctors who emphasized the importance of chemical analysis for the diagnosis of the disease. His discovery of proteinuria in multiple myeloma has long been the only biochemical test for cancer until the seventies of the twentieth century, with the discovery of carcinoembrion antigen (CEA) and alpha-fetoprotein (alpha-FP) It can rightly be said that a protein named after him is the first tumor marker in the history of medicine.
\end{abstract}

Acta Medica Medianae 2019;58(1):125-130.

Key words: Bence Jones protein, multiple myeloma, history of medicine

University of Niš, Faculty of Medicine, Niš, Serbia

Clinic for Hematology, Clinical Center Niš, Serbia

Contact: Nenad Govedarović

Blvd. dr Zoran Djindjić 48, 18000 Niš, Serbia

E-mail: nenadgovedarovic@yahoo.com

\section{Uvod}

Termin Bens Džonsov protein (Bence Jones) je danas opšteprihvaćen naziv za belančevinu opisanu u mokraći bolesnika sa multiplim mijelomom. Zanimljivo je da Bens Džons nije prvi dao opis ovog proteina, ali je prepoznao njegov značaj u dijagnostici mijeloma.

Priča o ovom epohalnom otkriću odigrala se u prvoj polovini devetnaestog veka. Glavni akteri bili su doktor Vilijem Mek Intajer, doktor Henri Bens Džons (Henry Bence Jones) i doktor Džon Delrajmpli (John Dalrymple), baš kao i Tomas Aleksander Mek Bin (Thomas Alexander McBean), prvi jasno dokumentovani bolesnik sa multiplim mijelomom.

\section{Tajanstvena bolest gospodina Mek Bina}

Tokom 1843. godine, Aleksander Tomas Mek Bin, ugledni četrdesetčetvorogodišnji trgovac iz Londona, počeo je da se pojačano zamara što ga je pri- moravalo da zastaje pri dužem hodu. Primetio je da ima i češći nagon za mokrenjem, kao i da mu je "veš stalno natopljen mokraćom iako nije mokrio" (1).

Dinamične prirode, Mek Bin septembra 1844. godine odlazi na višednevni boravak u Škotsku, u prirodu. Pri pokušaju izlaska iz jedne podzemne pećine zadobija oštar bol, "kao da mu je nešto prsnulo unutar grudi", što ga je nateralo da legne na tlo i neko vreme ostane ležeći nepokretan. Nakon prespavane noći u obližnjem odmaralištu, bol se smanjio. Po dolasku, Mek Bin se javlja svom ordinirajućem lekaru, Tomasu Votsonu, lekaru opšte prakse, koji je radio u jednoj državnoj bolnici u Londonu. Doktor Votson zaključuje da se radi o upali plućne maramice, te bolesniku aplikuje gipsani zavoj oko grudnog koša, donekle mu olakšavajući bolove koji su se javljali pri disanju i pri najmanjem pokretu ruku (2). Ovo je Mek Binu omogućilo da se koliko toliko, vrati svom svakodnevnom poslu. Mesec dana kasnije bolovi su se ponovo javili te je, od strane mesnog hirurga lečen "pijavicama i flebotomijom radi prečišćavanja krvi" (3).

U proleće 1845, Mek Bin je usled višekratnog "terapijskog ispuštanja krvi" postao adinamičan, bled, a uskoro su mu se pojavili i otoci lica i gležnjeva. Ponovo je posetio svog lekara, dr Votsona, koji mu je prepisao terapiju sa smešom gvožđa citrata i kinina i opijumom. Nakon ovoga, opšte stanje i apetit Mek Bina su se značajno popravili, te ponovo odlazi u Škotsku gde provodi leto.

Septembra 1845, Mek Bin se ponovo vraća u London, sada već jako iscrpljen, sa oslabljenim apetitom, nadutošću i epizodama dijareje, kao i otocima nogu i bolovima u grudima i krsno-slabinskom poja- 
su kičme. Ponovo biva sagledan od strane doktora Votsona, koji uključuje terapiju toplim kupkama, amonijakom i kamforom. Budući da stanje bolesnika postaje sve lošije, 30. oktobra 1845. godine, konsultovan je doktor Vilijem Mek Intajer, u to vreme pedesettrogodišnji lekar - konsultant iz lečilišta Metropoliten i Zapadne opšte bolnice (Metropolitan Convalescent Institution, Western General Dispensary) u delu Londona Sveti Meriliboun (St. Marylebone) (4).

Doktor Mek Intajer je saslužao žalbe obolelog na malaksalost i bolove u kostima i konstantovao izražene periferne edeme. Razmatra mogućnost da se radi o mogućem oboljenju bubrega, uzeo je uzorak urina za analizu. Analizom urina nije dokazao šećer, ali je primetio da je urin zamućen, kiseo i velike specifične težine (1035). Zatim je ispitivao prisustvo albumina. U to vreme, standardni test za dokazivanje albumina bio je zagrevanje urina do temperature nešto niže nego što je tačka ključanja, a zatim rashlađivanje istog uzorka. Zagrevajući urin, primetio je da pri tremperaturi nešto višoj od 50C stepeni dolazi do stvaranja precipitata. Ovo je bila temperatura niža nego što je potrebno za taloženje albumina. Daljim zagrevanjem, ovaj precipitat se rastvarao. Mek Intajer nije imao ideju o čemu se radi, ali je zapazio da nije reč o albuminu $(4,5)$.

Izgleda da doktor Votson pri svojim prethodnim pregledima nije ispitivao urin gospodina Mek $\mathrm{Bi}-$ na, već je bio prisutan kad je doktor Mek Intajer analizirao urin ili mu je to bilo saopšteno. Slično današnjim čestim dupliranjem laboratorijskih analiza, i doktor Votson je nezavisno poslao jedan uzorak urina na analizu, tada tridesetjednogodišnjem doktoru Bensu Džonsu, tada već poznatom „lekaru i hemičaru", u bolnicu Sent Džordž. U propratnom pismu napisanom u subotu, 1 . novembra 1845 . godine, doktor Votson kaže:

„Dragi doktore Džons,

(...) U epruveti se nalazi urin jako visoke specifične težine. Zagrevanjem postaje lako zamućen. Dodavanjem azotne kiseline postaje penušav i poprima crvenkasti odsjaj i razbistri se, ali daljim hlađenjem opet postaje zamućen. Novim zagrevanjem se ponovno rastvara. Šta je to ?" $(1,3,4,6,7)$.

Henri Bens Džons je ponovio test sa uzorkom urina i dobio identičan rezultat. Primetio je još da dodavanjem azotne kiseline nastaje precipitat koji se zagrevanjem rastvara, a zatim ponovnim hlađenjem stvara fenomen koji su opisali doktor Votson i Mek Intajer. Džons je obavio opsežne analize i naposletku zaključio da je reč o specifičnom oksidu albumina, tj. „hidratisanom dioksidu albumina". Procenio je da na 1000 zapreminskih delova urina dolazi 66,97 delova dioksida albumina i da je ovaj odnos ekvivalentan udelu albumina u normalnoj krvi. U skladu sa ovakvom procenom, izvesna količina ove "albuminske materije se prelivala u urin", pri čemu je njegova koncentracija i u krvi i u mokraći ostajala nepromenjena. Doktor Bens Džons je izračunao da je bolesnik gubio oko 60 grama belančevina dnevno putem urina, što predstavlja količinu koja se ne može kompenzovati nikakvim unosom putem hrane. O ovome je sačinio izveštaj i prosledio ga doktoru Mek Intajeru, navodeći da bolesnik ima "albumozuriju” $(5,7)$. Nekoliko dana nakon ovih događaja, oboleli Mek Bin je preminuo.

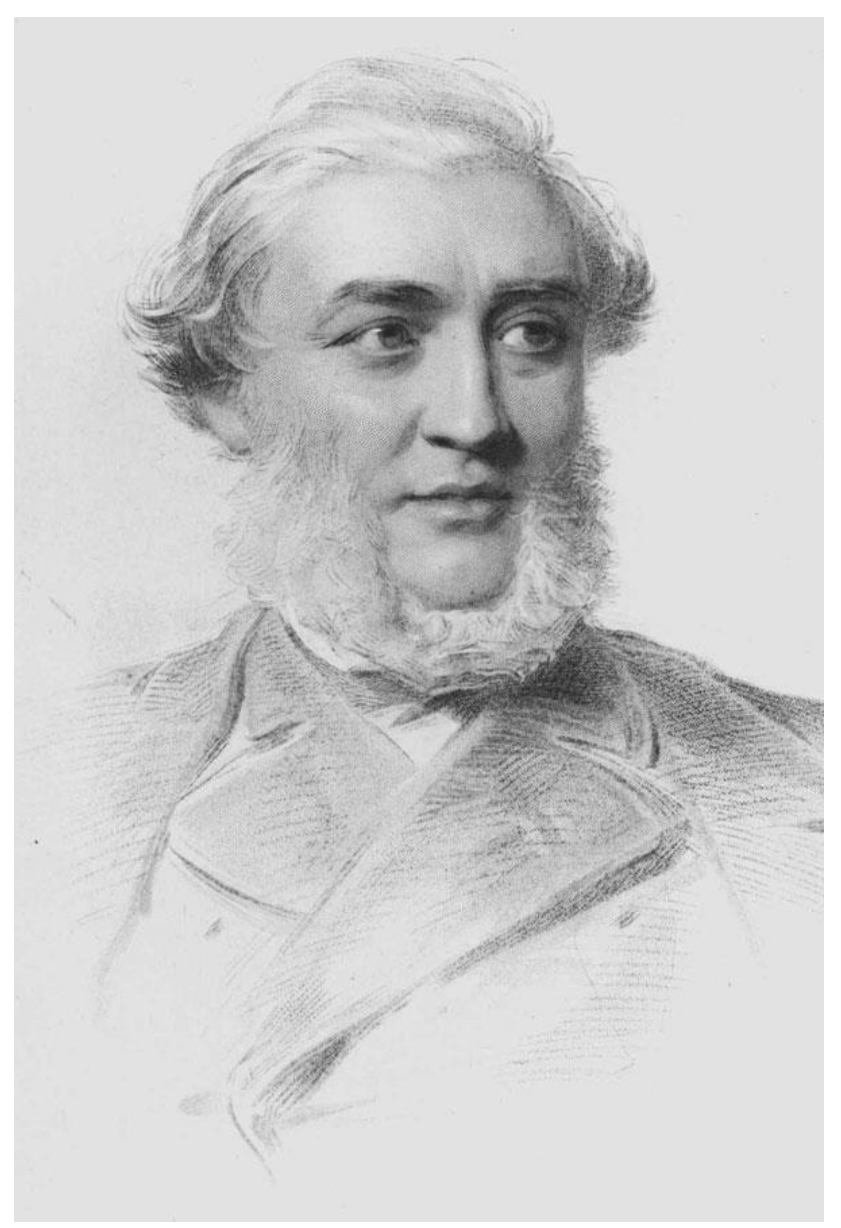

Slika 1. Henry Bence Jones (1813-1873)

\section{Neobjašnjiv nalaz na obdukciji}

Osim saznanja o bolovima u kostima, na zahvaćenost skeleta se nije sumnjalo tokom trajanja bolesti. Trideset i šest časova nakon smrti Mek Bina, izvršena je obdukcija. Obdukcija je sprovedena od strane doktor Šoa (Shaw) u prisustvu njegovih kolega, Votsona, Ben Džonsa i Mek Intajera. „Rebra su se ugibala pod ošticom skalpela. Toliko su bila meka i krhka da su se lako mogla seći nožem. Unutrašnjost rebara bila je ispunjena glatkom želatinoznom supstancom krvavo crvene boje. Sternum je bio mekan, krhke građe i pucketao je pri pomeranju. Grudni i slabinski kičmeni pršljenovi su bili slične građe kao i rebra. Štaviše, bubrezi su makroskopski i mikroskopski izgledali normalni" $(8,9)$.

$\mathrm{Na}$ mogućnost sekundarne amiloidoze u sklopu mijeloma ukazivala je dijareja, slabost, uvećanje jetre, gasovi, gubitak apetita, otoci gležnjeva, nadutost lica i masivna proteinurija u urinu. Ipak, obdukcijski nalaz normalne građe srca i bubrega i „uve- 
ćane jetre koja je uredne strukture", činila je dijagnozu amiloidoze neizvesnom. Izgleda neverovatno da je amiloidoza previđena, budući da su u to vreme voštane promene karakteristične za amiloidozu jetre redovno bile sagledavane.

Doktor Mek Intajer je skromno zaključio „da njegov udeo u traženju prave istine ovde postaje nedovoljan", predlažući da se slučaj prikaže drugim istraživačima "koji imaju dar i kvalifikacije da sprovedu istraživanje na višem nivou, kako bi se identifikovalo očigledno do sada nezabeleženo patološko stanje mokraće" (10).

\section{Treći čovek, Džon Delrajmpli}

Doktor Džon Delrajmpli, tada hirurg u Kraljevskoj očnoj bolnici (Royal Ophthalmic Hospital) i član Udruženja mikroskopista, dobio je zadatak da ispita dva lumbalna pršljena i rebro, koji su pripadali preminulom Mek Binu.

Utvrdio je da bolest nastaje u šupljikavom delu kosti, stvarajući crvenkaste formacije ovalnog ili nepravilnog oblika koje su se providile kroz periost.
Šupljine ovih kostiju bile su ispunjene želatinoznom masom čiji su najveći udeo činile krupne ovalne ćelije, dva puta veće od prosečnog eritrocita. Ove ćelije su često imale po dva jedra u kojima se jasno razaznavalo jedarce. Postojale su i pojedinačne krupne ćelije sličnih karakteristika koje su imale po tri jedra. Delrajmpli je zaključio da su opisane ćelije "odgovorne za razmekšanje kostiju (mollities osssium), da su kratkog života i da se nakon razgrađivanja izbacuju putem bubrežne cirkulacije". Kako Delrajmpli, tako je i Mek Intajer, verovao da je reč o malignoj bolesti kostiju (9).

Neposredno nakon ovoga, u toku 1846. godine, Delrajmpli objavljuje rad sa opisom postmortem nalaza u jednom patohistološkom časopisu. Henri Bens Džouns 1847. godine objavljuje svoja zapažanja u vidu kratkog pisma u Lancetu. Godinu dana kasnije on objavljuje i definitivni rad sa detaljnim opisom laboratorijskog nalaza i tehnike koju je koristio za analiziranje urina. Konačno, 1850. godine, Mek Intajer objavljuje svoj izveštaj, sagledan iz kliničkog ugla gledanja.
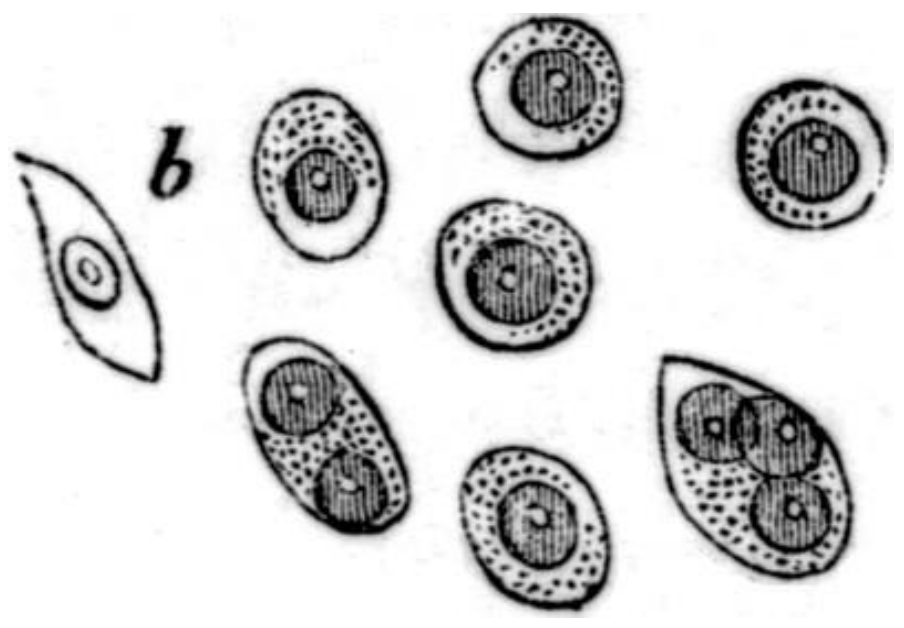

Slika 2. Crtež Džona Delrajmplija na kome je skicirao plazma ćelije viđene na mikroskopskom uzorku

Gledano sa strane, nije poznato šta je sprečilo tri eminentna lekara da objave jedinstveni koautorski izveštaj. U istoriji medicine nije poznat nijedan slučaj izveštavanja o istom bolesniku sačinjen od troje ljudi različitih specijalnosti (patolog, hemičar i kliničar), objavljen u tri različita časopisa, u periodu od četiri godine (9). Ipak, stalna kooperativnost i intenzivna razmena mišljenja ovih lekara umnogome podseća na preteču današnjih konferencija u istraživačkoj medicini.

\section{Prva otkrića iz histologije mijeloma}

Termin „plazma ćelija” prvi put je upotrebio Valdejer (Waldeyer) 1875. godine. On je opisao krupne ćelije sa granuliranom citoplazmom, ali nije po- menuo njihovo ekscentrično postavljeno jedro, niti perinuklearno rasvetljenje koje je sadržalo Goldžijev aparat (Golgi apparatus). Vrlo verovatno je da je Valdejer opisao mast ćeliju tkiva. Detaljan opis plazma ćelije srećemo u izveštajima Ramona Kahala (RamoÂn y Cajal) iz 1890. godine koji se bavio studijom sifilističnog kondiloma. Kahal je bio uverenja da su plazma ćelije bile normalni konstituenti vezivnog tkiva (3).

Rajt (Wright) 1900. godine objavljuje izveštaj o pedesetčetvorogodišnjem bolesniku sa tumorom grudnog koša i bolovima u kostima. Radiografija (rendgenski zraci su otkriveni svega tri godine ranije) je pokazala rasvetljenja na 5 . i 8 . rebru sa leve strane i 7. i 8. rebru sa desne strane grudnog koša. Ujedno je postojala "albumosurija" $\mathrm{i}$ anemija. Pri ob- 
dukciji opisan je tumor koji se sastojao od ćelija sa ekscentrično položenim jedrom i jako bojivim hromatinom, pri čemu su neke od ćelija sadržale i po dva jedra. Zaključuje da je reč o plazma ćelijama ili njihovim neposrednim potomcima. Rajt je takođe opisao i plazma ćelije u normalnoj koštanoj srži i naglasio da je multipni mijelom „neoplazma koja potiče iz crvene kostne srži i vodi poreklo isključivo od plazma ćelija" (11).

\section{Prepoznata je nova bolest}

Multipli mijelom je verovatno u ljudskoj vrsti prisutan vekovima. Morze (Morse) je sa saradnicima 1974. godine objavio izveštaj o četiri moguća slučaja mijeloma, opisujući promene na skeletima američkih Indijanaca koji datiraju iz 200 godine posle n.e. Morze je opisao jasno ograničene litičke lezije na kostima bez okolne skleroze niti znakova stvaranja nove kosti (12).

Prvi publikovani opis mijeloma u Americi potiče od Vebera (Weber) i saradnika iz 1898. godine. Izveštaj opisuje bolesnicu sa progresivnim bolovima u kostima i kifozom, koja je umrla od mijeloma, a par godina kasnije (1903) izveštava o bolesniku sa sličnim tegobama i proteinurijom od 15 grama dnevno. Autori su pretpostavili da je mesto produkcije Bens Džonsovog proteina koštana srž, da nastaje iz rezidua citoplazme nakon lize ćelija, te da je njegovo prisustvo od "fatalnog značaja" ukazujući skoro uvek, ako ne i uvek, da bolesnik boluje od multipnog mijeloma. U svom zaključku, Veber navodi važnost upotrebe rendgenovih zraka pri sumnji na zahvaćenost skeleta.

Dijagnoza mijeloma je umnogome olakšana uvođenjem aspiracione punkcije koštane srži. U svojim izveštajima, Arinkin (Arinkin, 1929) i Rozental i Vogel (Rozenthal et Vogel, 1938) naglasili su važnost sternalne punkcije kod bolesnika sa anemijom nejasnog uzroka i poremećajima skeleta (3).

\section{Dalja saznanja o Bens Džonsovom proteinu}

Brojni istraživači ostali su zapisani u priči o Bens Džonsovom proteinu. Bredšo (Bradshaw) je 1898. godine utvrdio da hrana nema uticaj na količinu ovog proteina izlučenog u dnevnom urinu. Voters (Walters) 1921. godine daje izveštaj o studiji na tri bolesnika sa mijelomom, da dnevni proteinski unos nema uticaja na količinu proteinurije, da ne postoji diurnalna varijacija, odnosno da je stepen ekskrecije ovog proteina prilično ujednačen tokom dana. Voters zaključuje da je Ben Džonsov protein endogenog porekla i da verovatno nastaje u krvi koja sekretuje abnormalne ćelije kostne srži $(3,8)$.

Bejn Džons i Vilson (Bayne-Jones et Wilson) 1922. godine dokazuju da se Bens Džonsov protein sastoji od dve grupe sličnih, ali ne identičnih proteina, označivši ih kao grupa I i grupa II. Tek 1956. godine, sa napretkom laboratorijske tehnike, Korngold \& Lipari pokazuju da antiserum na Bens Džonsov protein reaguje i sa ovim mijelomskim proteinima. U čast ovih istraživača, dve klase Bens Džonsovih proteina označene su kao kappa i lambda.

Sto sedamnaest godina od prvog opisa proteina, Edelma i Gouli (Edelmman et Gally, 1962) po- kazuju da laki lanci dobijeni iz monoklonskog proteina IgG i Bens Džonsovog proteina iz urina istog bolesnika poseduju identični redosled aminokiselina, identičnu molekulsku masu, slično ponašanje pri spektroflourometriji i identičan prikaz pri hromatografiji na celuloznoj traci i elektroforezi na gelu. Ovim je utvrđeno da Bens Džonsov protein vodi poreklo od lakih lanaca imunoglobulina.

Vilson (Wilson) 1964. godine daje opis metode imunofiksacije ili direktne imunoelektroforeze, kada aplikuje antiserum na površinu agara neposredno po završetku elektroforeze. Imunofiksacija je korisna u prepoznavanju malih monoklonskih lakih lanaca koji se ne mogu dokazati standardnom imunoelektroforezom.

Napretkom nauke i usavršavanjem laboratorijskih tehnika, omogućeno je precizno kvantitativno i kvalitativno detektovanje monoklonske belančevine i podtipa lakih lanaca, čime je zaokružena dijagnostika mijeloma.

\section{Zaključak}

Identitet bolesnika u ovom prvom dokumentovanom opisu mijeloma ostao je nepoznat skoro čitav vek. Doktor Mek Intajer je u svojim prepiskama sa kolegama bolesnika uvek oslovljavao kao "gospodin M.", a u svojim izveštajima doktor Bens Džons ga nije identifikovao po imenu. Tek 1967. godine, pažljivom i mukotrpnom pretragom Registra umrlih lica za područje Londona, za prvi kvartal 1846. godine, kao i eliminacijom zasnovanom na podacima o prvom slovu imena, starosti, zanimanju i uzroku smrti, pronađen je posmrtni list i utvrđen identitet bolesnika. Bio je to gospodin Tomas Aleksander Mek Bin, preminuo 1. januara 1846. godine, dok je kao uzrok smrti navedena „,atrofija zbog albuminurije" (10).

Postojala su mišljenja nekih autora da bi, gledano sa istorijske distance, prikladniji naziv za mijelom bio „Mek Binova bolest sa Mek Intajerovom proteinurijom" (McBean's disease with Macintyre's proteinuria) (5). Termin „multipni mijelom", prvi put je upotrebio von Rustizky 1873. godine u svom opisu multipnih zona tumora koji je zahvatio koštanu srž. Ipak, trebalo je da prođe čitavih 16 godina pa da Oto Kaler (Otto Kahler) u svojim radovima o mijelomu iz 1889. godine uvede termin „H. B. Jones" proteinurija (7).

Danas kvalitativno i kvantitativno određivanje Bens Džonsovog proteina praktično predstavlja deo rutinskih analiza za dijagnostiku i skrining bolesnika sa mijelomom i bolestima skeleta. Iako Henri Bens Džons nije taj koji je prvi prepoznao svojstva urina obolelog, njegova zasluga je u tome da je prepoznao važnost ovog proteina kod bolesnika sa mijelomom. Smatra se pionirom u medicinskoj hemiji i jedan je od prvih lekara koji je naglašavao važnost hemijskih analiza za dijagnozu bolesti. Njegovo otkriće proteinurije u multipnom mijelomu dugo je važilo za jedini biohemijski test za kancer, sve do sedamdesetih godina dvadesetog veka, sa otkrićem karcinoembrionskog antigena (CEA) i alfa fetoproteina (alfa-FP) (9). S pravom se može reći da protein nazvan po njegovom imenu predstavlja prvi tumorski marker u istoriji medicine. 


\section{Kratke crtice iz biografije}

Vilijem Mek Intajer (William MacIntyre; 1791-1857)

Vilijem Mek Intajer je radio kao lekar u ordiniciji smeštenoj u području Merliboun (84 Harley Street, Marylebone) u središnjem delu Londona. Danas, ovaj urbani deo odiše elegancijom i nosi tradiciju najbolje britanske konsultativne medicine.

Interesantno je da je Mek Intajer podjednako bio posvećen humanitarnom radu, budući da je kao lekar radio u dvema ustanovama za "nemoćne i bolesne" (Metropolitan Convalescent Institution i Western General Dispensary). Uslovi rada u ovakvim boInicama podrobno su opisani u delu "Oliver Tvist" Čarlsa Dikensa, objavljenog 1838. godine (1).

Džon Delrajmpli (John Dalrymple; 1804-1852)

Rođen u Norviču, u Engleskoj, (Norwich), završio medicinu na Univerzitetu u Edinburgu, Škotska (Edinburgh), a kasnije postaje oftalmolog, odnosno "hirurg za oko" u Kraljevskoj očnoj bolnici (Royal Ophthalmic Hospital) u Londonu. U medicini ostaje zapamćen po svom opisu histopatološkog nalaza kod obolelih od mijeloma, u članku naslovljenom kao „O mikroskopskim odlikama razmekšanja i krhkosti kostiju" (On microscopic characteristics of mollitas and fragilitas ossium) (5).

Henri Bens Džons (Henry Bence Jones; 1813-1873)

Henri Bens Džons je rođen u Safoku, u Engleskoj (Suffolk), 31. decembra 1813. godine. Nakon završenog crkvenog koledža u Kembridžu (Cambridge), odlučuje da se ne pridruži crkvi, već 1837. godine odlazi u bolnicu Sveti Džordž (Saint George) kako bi učio za apotekarskog pomoćnika. Kasnije će za ovaj period života Bens Džons tvrditi da mu je podario najdragocenije iskustvo za sav njegov radni vek (1).

Godinu dana kasnije, podstaknut saznanjima i novinama koje se primenjuju u svetu medicine, Bens Džons se upisuje u novoosnovanu medicinsku školu pri bolnici. Sa širokim interesovanjima pristupa učenju, od Faradejevih lekcija o elektricitetu, do toga kako koristiti u to vreme tek uveden u praksu, ali još uvek kontraverzan, stetoskop.

Nakon završenog koledža, odlazi na šestomesečne studije u Gesen (Giessen), u Nemačku, na šestomesečno usavršavanje u hemijskoj laboratoriji Libig (Liebig). U to vreme, u medicinskim školama se malo pažnje poklanjalo hemizmu tkiva, već se držalo teorije da se dijagnoza postavlja na osnovu simptomatologije i nalaza na pojedinom organu. Iskustvo stečeno u radu u ovoj laboratoriji stvorilo je u njemu doživotnu želju za proučavanjem ljudskog hemizma i primenom hemije u medicini. Nije preterano reći da, zajedno sa drugim učenicima laboratorijske škole u Libigu, Bens Džouns postaje okosnica nečega iz čega će se, kao posebna specijalnost, izroditi klinička hemija (7).

\section{References}

1. Rathore R, Coward RA, Woywodt A. What's in a name? Bence Jones protein. Clin Kidney J 2012; 5: 478-83. [CrossRef][PubMed]

2. Kyle RA, Rajkumar SV. Multiple Myeloma. Blood 2008; 111(6): 2962-72. [CrossRef][PubMed]

3. Kyle RA. Multiple Myeloma: an odyssey of discovery. Br J Haematol 2000; 111(4): 1035-44. [CrossRef][PubMed]

4. Kyle RA. Multiple Myeloma: how did it begin? Mayo Clin Proc 1994; 69(7): 680-3. [CrossRef][PubMed]

5. Kyle RA. Henry Bence Jones - Physician, chemist, scientist and biographer: a man for all seasons. $\mathrm{Br}]$ Haematol 2001; 115(1): 13-8. [CrossRef][PubMed]

6. Kahn SN. Dear Dr. [Bence] Jones... Clin Chem 1991; 37(9): 1557-8. [CrossRef][PubMed]
7. Rosenfeld L. Henry Bence Jones (1813-1873): the Best "Chemical Doctor" in London. Clin Chem 1987; 33(9): 1687-92. [CrossRef][PubMed]

8. Stone MJ. Henry Bence Jones and his protein. J Med Biogr 1998; 6(1): 53-7. [CrossRef][PubMed]

9. Hajdu SI. A Note from history: the First biochemical test for detection of cancer. Ann Clin Lab Sci 2006; 36(2): 222-3. [CrossRef][PubMed]

10. Clamp JR. Some aspects of the first recorded case of multiple myeloma. Lancet 1967; 2(7530): 1354-6. [CrossRef][PubMed]

11. Wright JH. A case of multiple myeloma. Transactions of the Association of American Physicians 1900; 15: 137-47.

12. Morse D, Dailey RC, Bunn J. Prehistoric multiple myeloma. Bull N Y Acad Med 1974; 50(4): 447-58. [CrossRef][PubMed] 


\title{
BENS DŽONSOV PROTEIN - PRVI TUMORSKI MARKER U ISTORIJI MEDICINE
}

\begin{abstract}
Nenad Govedarović
Univerzitet u Nišu, Medicinski fakultet Niš, Srbija

Klinika za hematologiju, Klinički centar Niš, Srbija

Kontakt: Nenad Govedarović

Bul. dr Zorana Đinđića 48, 18000 Nišs, Srbija

E-mail:nenadgovedarovic@yahoo.com

Termin Bens Džonsov protein (Bence Jones) danas je opšteprihvaćen naziv za belančevinu opisanu u mokraći bolesnika sa multiplim mijelomom. Danas, kvalitativno i kvantitativno određivanje Bens Džonsovog proteina praktično predstavlja deo rutinskih analiza za dijagnostiku i skrining bolesnika sa mijelomom i bolestima skeleta. Iako Henri Bens Džons nije bio taj koji je prvi prepoznao svojstva urina obolelog, njegova zasluga je u tome da je prepoznao važnost ovog proteina kod bolesnika sa mijelomom. Smatra se pionirom u medicinskoj hemiji i jedan je od prvih lekara koji je naglašavao važnost hemijskih analiza za dijagnozu bolesti. Njegovo otkriće proteinurije u multipnom mijelomu dugo je važilo za jedini biohemijski test za kancer, sve do sedamdesetih godina dvadesetog veka i otkrića karcinoembrionskog antigena (CEA) i alfa fetoproteina (alfa-FP). S pravom se može reći da protein nazvan po njegovom imenu predstavlja prvi tumorski marker $u$ istoriji medicine.
\end{abstract}

Acta Medica Medianae 2019;58(1):125-130.

Ključne reči: Bens Džonsov protein, multipni mijelom, istorija medicine 